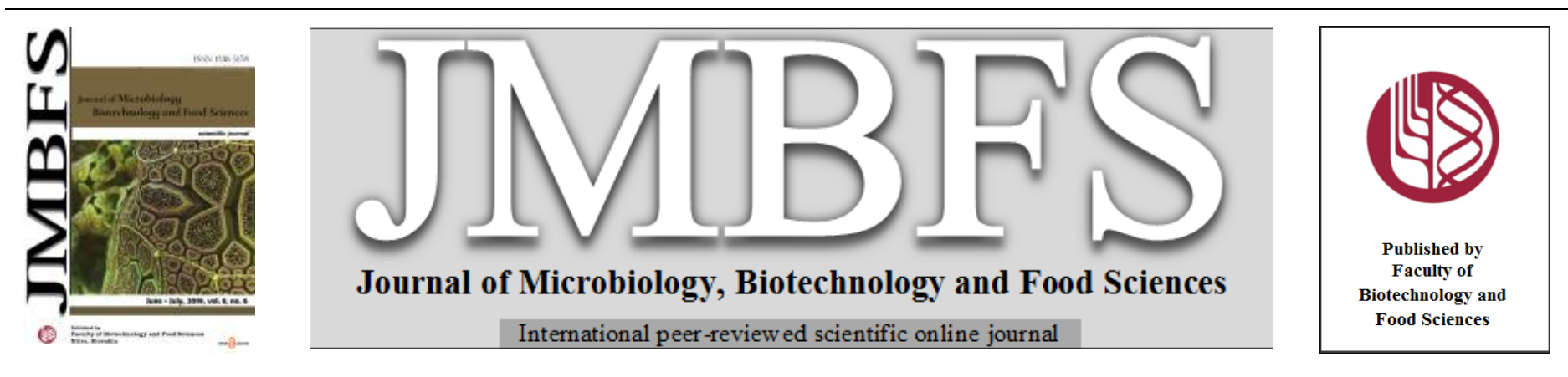

\title{
BIOFILM FORMATION AND GENETIC DIVERSITY OF LACTOBACILLUS PLANTARUM STRAINS ORIGINATED FROM FRANCE AND UKRAINE
}

\author{
Nataliia Limanska*1, Andrii Merlich ${ }^{1,2}$, Mykola Galkin ${ }^{1}$, Nataliia Vasylieva $^{1}$, Yvan Choiset ${ }^{2}$, Tetiana Ivanytsia ${ }^{1}$, Maryna Zlatohurska $^{1}$, \\ Volodymyr Ivanytsia ${ }^{1}$, Jean-Marc Chobert ${ }^{2}$, Thomas Haertlé ${ }^{2}$
}

\author{
Address(es): PhD Nataliia Limanska, \\ ${ }^{1}$ Odessa National I.I. Mechnikov University (ONU), Biological Faculty, Microbiology, Virology and Biotechnology Department, Dvorianska str., 2, 65082, Odessa, \\ Ukraine, phone number:+38 0487317151. \\ ${ }^{2}$ French National Institute for Agriculture Research (INRA), UR1268, Biopolymères, Interactions, Assemblages, BP 71627, rue de la Géraudière, 44316 Nantes Cedex \\ 3, France.
}

*Corresponding author: limanska@onu.edu.ua

doi: 10.15414/jmbfs.2019.8.6.1326-1331

\begin{abstract}
ARTICLE INFO
ABSTRACT

Received 4. 8. 2018

Revised 11. 2. 2019

Accepted 14. 2. 2019

Published 1. 6. 2019

Evaluation of Lactobacillus plantarum strains perspective for plant protection or fermentation of food of plant origin should include tests on abilities to attach to plant surfaces and to form biofilms. Comparing RAPD-profiles with these properties and also with geographical origin of the strains is necessary to find out the possibility of rapid selection of the strains and tracking their dissemination. Biofilm formation and RAPD-PCR profiles of 30 strains of $L$. plantarum isolated from grape must and pickles originated from France and Ukraine were compared. All isolates were able to attach to Lepidium sativum seedlings and form biofilms of different types.

Regular article Amount of attached cells varied from $(7.8 \pm 0.2) \times 10^{4}$ to $(2.1 \pm 0.3) \times 10^{3} \mathrm{CFU} / \mathrm{cm}^{2}$. The most developed biofilms were formed on open 2 access shoots, leaves, seed coat shells. On roots this ability was strain dependent: the majority of French isolates (77.0\%) formed separated microcolonies without developed matrix layer. Among Ukrainian isolates, $47.1 \%$ of the strains showed the same tendency, and in $41.2 \%$ of the strains individual attached cells without formation of microcolonies were observed. The level of initial attachment of bacterial cells to roots did not coincide with the level of subsequent formation of biofilms. Gene $p \ln A$ was detected in $28.1 \%$ of isolates. All $p \ln A$ possessing strains except the one formed microcolonies or biofilms with developed matrix. Lactobacilli could eliminate the biofilms of Agrobacterium tumefaciens $\mathrm{pJZ}$ from tomato roots in 75.0 - $100 \%$ of tested samples depending on a strain and method of inoculation. No clear association between the geographical origin of the L. plantarum strains and clustering by RAPD-PCR analysis was found. Two strains with high level of biofilm formation were grouped in one subcluster.
\end{abstract}

Keywords: Lactobacillus plantarum, biofilms, plnA locus, RAPD-PCR

\section{INTRODUCTION}

L. plantarum is one of the most well studied lactobacilli colonizing plants (Hammes and Hertel, 2006). Presence of L. plantarum in must at detectable levels depended on the origin of the samples. In grapes from Greece vineyards $L$. plantarum dominated during the middle and final stages of fermentation even in the samples in which initial populations of lactic acid bacteria (LAB) were below the detection limit (Nisitou et al., 2015). In samples from South Africa wines $L$. plantarum was the dominant species in grape juice, but could not be detected during the later stages of wine production (du Plessis et al., 2004). In samples from Bordeaux vineyards (France) L. plantarum were revealed on grape on the day of harvest at a concentration of 2 cells $/ \mathrm{ml}$ but after they could not be found anymore. In samples from another French wine-producing region - Cognac, $L$. plantarum were isolated on the first day of wine fermentation at a concentration of $10^{4}$ cells $/ \mathrm{ml}$, but as in the previous case, the population after decreased below the detectable level (Lafon-Lafourcade $\boldsymbol{e t}$ al., 1983). Some L. plantarum strains from grape must together with Oenococcus oeni were proposed for development of starter cultures for the controlled process of malolactic fermentation improving special organoleptic characteristics of certain wines (Bauer and Dicks, 2004; Bravo-Ferrada et al., 2013; Testa et al., 2014).

L. plantarum from fermenting plant material were characterized by strong antagonistic activity (Ben Omar et al., 2008; Knoll et al., 2008; Singh and Ramesh, 2008; Piasecka-Jozwiak et al., 2013). Antagonistic properties of LAB are widely used in food fermentation (Ben Omar et al., 2008; Singh and Ramesh, 2008; Çon and Karasu, 2009), probiotics (Martins et al., 2013) and become promising for plant protection (Visser et al., 1986; Trias et al., 2008; Hoda et al., 2011; Lutz et al., 2012). It could be hypothesized that being the representatives of normal plant microbiota lactobacilli (Hammes and Hertel, 2006) could colonize plants and protect them from phytopathogens. Adhesion of
L. plantarum is well studied on a model of epithelial cells (Tallon et al., 2006; Velez et al., 2007). But there is scarce information about the attachment of lactobacilli to plant surfaces. Reina et al. (2002) compared adhesion of bacteria from several genera to fresh cucumber fruit surfaces. Salmonella typhimurium and Staphylococcus aureus surprisingly adsorb to cucumber surfaces at higher levels than L. plantarum. Also the reported levels of adhesion of L. plantarum were lower for dewaxed fruits (Reina et $\boldsymbol{a l . , 2 0 0 2}$ ). Tests on ability to attach and to form biofilms on plant surfaces should be carried out with the strains intended for plant protection or fermentation of food products of plant origin.

Strains of $L$. plantarum were characterized by their high diversity within the species that can be revealed by Random Amplification of Polymorphic DNA (RAPD)-PCR typing (Ben Omar et al., 2008; Pisano et al., 2011; BravoFerrada et al., 2013). The results of RAPD-analysis may be used for development of primers for detection of L. plantarum strains (Galanis et al., 2015), to track the survival of lactobacilli during their consumption as probiotics (Mahenthiralingam et al., 2009) or to find out the ways of dissemination of lactobacilli during globalization processes (Song et al., 2016). Analysis of genetic diversity of L. plantarum strains from France and Ukraine will allow to establish whether RAPD-analysis could be helpful to reveal the geographical origin of the strains from two distant regions of the Europe. These data could be implemented in development of methods tracking the dissemination of starter or probiotic cultures important for food industry, medicine or plant protection. Moreover, investigations of possible association between the useful technological properties, such as biofilm formation, and RAPD-profiles are necessary to find out the possibility of rapid evaluation of the strains perspective for plant protection or food fermentation.

The aim of the present work was to study the diversity of L. plantarum strains originated from France and Ukraine comparing their RAPD-PCR profiles and ability to form biofilms. 


\section{MATERIAL AND METHODS}

\section{Bacterial strains}

Thirteen strains of $L$. plantarum isolated in France from grape must and seventeen $L$. plantarum strains isolated in Ukraine from must and pickles were included in the experimental set up (Tab 1).

Strains were stored at $-80^{\circ} \mathrm{C}$ in a Collection of Bacterial Cultures of Odessa National I.I. Mechnikov University (ONU). MRS medium (de Man et al., 1960) and standard conditions $\left(37^{\circ} \mathrm{C}, 24-48 \mathrm{~h}\right)$ were used for cultivation.

Phytopathogenic strain Agrobacterium tumefaciens pJZ labeled with GFP was kindly provided by Dr. Clay Fuqua (USA) and Dr. Igor Golovlev (Sweden) Agrobacteria were cultivated in LB broth (Bertani, 1951) at $28^{\circ} \mathrm{C}$ and stored at $80^{\circ} \mathrm{C}$ in $30 \%$ glycerol

Table 1 Origin of the strains used in this study

\begin{tabular}{|c|c|c|}
\hline Strain & $\begin{array}{l}\text { Source of } \\
\text { isolation }\end{array}$ & $\begin{array}{c}\text { Country of } \\
\text { isolation }\end{array}$ \\
\hline $\begin{array}{l}\text { L. plantarum ONU 12, ONU 311, } \\
\text { ONU 312, ONU 313, ONU 333, } \\
\text { ONU 335, ONU 337, ONU 339, } \\
\text { ONU 340, ONU 342, ONU 345, } \\
\text { ONU 348, ONU 349, ONU 350 }\end{array}$ & Grape must & Ukraine \\
\hline $\begin{array}{l}\text { L. plantarum ONU 351, ONU 352, } \\
\text { ONU 353, ONU 354, ONU 355, } \\
\text { ONU 356, ONU 357, ONU 359, } \\
\text { ONU 362, ONU 363, ONU 364, } \\
\text { ONU 365, ONU 471 }\end{array}$ & Grape must & France \\
\hline L. plantarum ONU 472, ONU 475 & Sauerkraut & Ukraine \\
\hline L. plantarum ONU 476 & $\begin{array}{l}\text { Fermented pickled } \\
\text { tomatoes }\end{array}$ & Ukraine \\
\hline $\begin{array}{l}\text { L. plantarum UCM B-2709, UCM } \\
\text { B-2694 }\end{array}$ & $\begin{array}{l}\text { Reference strains, } \\
\text { Ukrainian } \\
\text { Collection of } \\
\text { Microorganisms }\end{array}$ & Ukraine \\
\hline
\end{tabular}

\section{Test plants}

Seeds of garden cress Lepidium sativum L. var. Azhur were sterilized with $25 \%$ of $\mathrm{H}_{2} \mathrm{O}_{2}$ for $60 \mathrm{sec}$ and washed three times with sterile distillated water (SDW) After, seeds were brought into sterile Petri dishes with wet filter paper and left for three days at $20-24^{\circ} \mathrm{C}$ to germinate. Seedlings of garden cress were used in fast screening of $L$. plantarum strains for ability of attachment and biofilm formation.

Seeds of tomatoes Lycopersicon esculentum Mill. var. Ballada were sterilized as described above and left to germinate for 7 days. Being a classical model of studying crown gall pathogenesis, tomato plants were used in experiments with competitive adhesion and biofilm formation of $L$. plantarum and plant pathogen Agrobacterium tumefaciens $\mathrm{pJZ}$

\section{Attachment and biofilm formation}

LAB cultures were cultivated overnight in MRS broth at $37^{\circ} \mathrm{C}$ till the concentration of $10^{8} \mathrm{CFU} / \mathrm{ml}$ measured with spectrophometer SmartSpec Plus (Bio-Rad, USA).

Attachment of bacteria to Lepidium sativum L. plants was studied by incubation of sterile root fragments with $\mathrm{LAB}$ cultures for $1 \mathrm{~h}$. After incubation, roots were washed two times in SDW, triturated in $10 \mathrm{mM}$ HEPES, $\mathrm{pH} 7.5$, and the resulted suspensions were inoculated on MRS plates and incubated $48 \mathrm{~h}$ at $37^{\circ} \mathrm{C}$ (Brisset et al., 1991). Totally 10 root fragments from each independent experiment were plated on LB agar to prove sterility and checked after $24 \mathrm{~h}$ of incubation at $37^{\circ} \mathrm{C}$ for presence of bacterial or fungal growth.

Seedlings and $L$. plantarum cultures were also placed into the sterile plastic wells and incubated at $37^{\circ} \mathrm{C}$ overnight to allow biofilm formation. After, the seedlings were treated with $96 \%$ ethanol for $15 \mathrm{~min}$ to fix the biofilms and stained with $0.1 \%$ acridine orange for $5 \mathrm{~min}$. Biofilms were observed on roots, stems, leaves and seed coat shells using a Primo Star PC, Carl Zeiss microscope, with a total magnification x600 and photographed with Olympus DCM (3.0 M pixels) camera. Three independent experiments for each strain were carried out, 10 images in each experiment per strain were analyzed.

\section{Competitive adhesion and biofilm formation}

Competition between $L$. plantarum and plant pathogen on a step of attachment and biofilm formation was studied on an example of Agrobacterium tumefaciens $\mathrm{pJZ}$ carrying $g f p$ gene encoding green fluorescent protein kindly provided by $\mathrm{Dr}$. Clay Fuqua (USA) and Dr. Igor Golovlev (Sweden). L. plantarum strains with the best abilities to biofilm formation were included in the experimental set up. As pathogenic agrobacteria preferentially penetrate plants via root system (Burr and Otten, 1999), roots of tomato seedlings as a model of surface of host plant were used. Three variants of experiment were carried out: (1) simultaneous inoculation of roots with lactobacilli and agrobacteria, (2) inoculation with lactobacilli with addition of agrobacteria after Lactobacillus biofilms have been formed, (3) inoculation with agrobacteria with subsequent treatment of their biofilms with lactobacilli. In case of competition experiments, $1 \times 10^{8} \mathrm{CFU} / \mathrm{ml}$ of each strain (overnight cultures) were simultaneously added to tomato seedlings in sterile 48 well polystyrol plates and left for $24 \mathrm{~h}$ of incubation at $28^{\circ} \mathrm{C}$. In the second variant, $L$. plantarum strains were added together with $1 \mathrm{ml}$ of MRS medium ( $100 \mu 1$ of overnight culture), and after $24 \mathrm{~h}$ of incubation the medium was substituted for $1 \mathrm{ml}$ of LB with $100 \mu \mathrm{l}$ of overnight agrobacterial culture followed by the next $24 \mathrm{~h}$ of incubation. In the third variant, agrobacteria in LB medium were added to roots, and after $24 \mathrm{~h}$ substituted for lactobacilli left for the next $24 \mathrm{~h}$ of incubation.

After incubation, seedlings (20-24 in each variant) were analyzed by fluorescent microscopy performed by the method of Barahona et al. (2010) with some modifications. Roots were excised, stained with $0.1 \%$ crystal violet for $40 \mathrm{~s}$, transferred on glass slides and analyzed with optical Carl Zeiss epifluorescence microscope system with 20x planachromat objective and Olympus DCM camera. Images of the biofilms on plant roots surfaces were obtained with BP490 filter set, a $505 \mathrm{~nm}$ dichroic filter and $530 \mathrm{~nm}$ long-pass emitter (EO530).

\section{RAPD-PCR}

DNA from the tested L. plantarum strains was isolated with the kit "DNA sorb" (Amplisens, Russia) and amplified with the primer M13 (Ben Omar et al., 2008) in 35 cycles of $94^{\circ} \mathrm{C}$ for $1 \mathrm{~min}, 45^{\circ} \mathrm{C}$ for $1 \mathrm{~min}$ and $72^{\circ} \mathrm{C}$ for 2 min (with preheating at $94^{\circ} \mathrm{C}$ for $3 \mathrm{~min}$ and post-elongation time for $5 \mathrm{~min}$ at $72^{\circ} \mathrm{C}$ ). A thermocycler "MyCycler" was used (BioRad, USA). The products were separated by agarose electrophoresis (1\% of agarose in Tris-acetate buffer), and the sizes of amplicons were measured using the GelAnalyzer2010 program.

The phylogenetic tree was constructed using the program Mega5 (Tamura et al., 2007,2011 ) basing on the method of maximum likelihood (ML) (Tamura $\boldsymbol{e t}$ al., 2011) and the Jukes-Cantor model (Jukes and Cantor, 1969). The statistical significance of the order of branching of the tree has been estimated using bootstrap analysis by constructing of the 1000 alternative replicas, or trees.

\section{PCR amplification of $p \ln A$ gene}

Amplification was carried out according to Ben Omar et al. (2008) with primers to $p \ln A$ gene described in Diep et al. (1996) and Remiger et al. (1996). Detection of products was carried out as described above.

\section{RESULTS}

\section{Attachment and biofilm formation}

All strains exhibited the ability to attach to Lepidium sativum seedling surfaces and to form biofilms. The intensity of biofilm formation was higher on shoots, leaves and seed coat shells (Fig1, D, E, F, Tab 2). In case of inoculation with all of the tested strains the biofilms were well-formed with microcolonies embedded in developed matrix layer. 


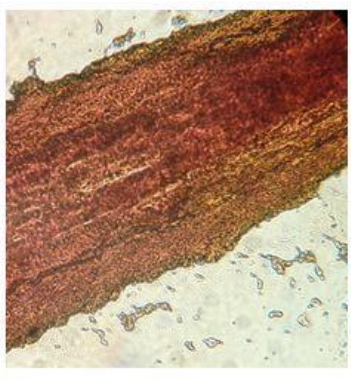

A

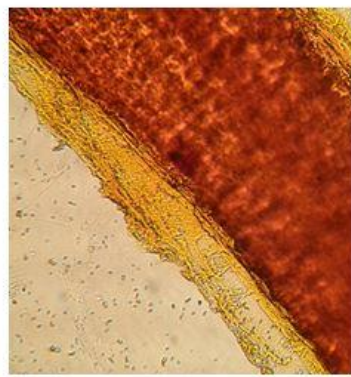

$\mathrm{C}$

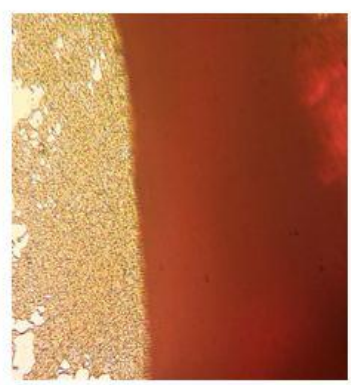

$\mathrm{E}$

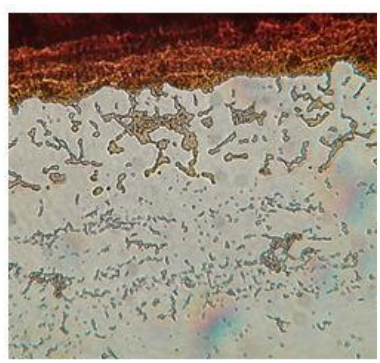

B

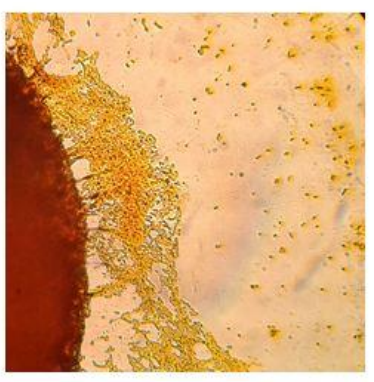

D

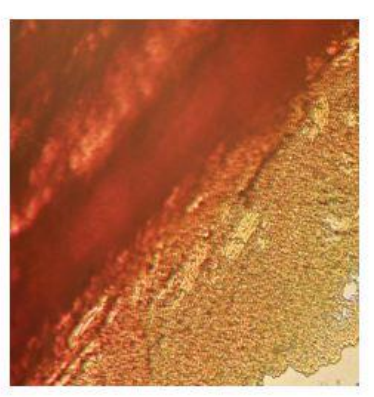

F
Figure 1 Biofilms of $L$. plantarum strains on Lepidium sativum: A - L plantarum ONU 335 on a root (individual attached cells without formation of microcolonies); B - L. plantarum ONU 345 on a root (individual well-formed microcolonies); $\mathrm{C}-L$. plantarum ONU 333 on a root (well-formed biofilm with gaps in the structure); D - L. plantarum ONU 12 on a seed coat shell (wellformed biofilm with microcolonies embedded in developed matrix); $\mathrm{E}-L$. plantarum ONU 12 on a leaf (well-formed biofilm with microcolonies embedded in developed matrix); F - L. plantarum ONU 333 on a shoot (well-formed biofilm with microcolonies embedded in developed matrix).

Opposite, on roots the level of biofilm formation was lower and depended on a strain (Fig 1, A, B, C, Tab 2).

The majority of French isolates had tendency to form separated well-formed microcolonies without the developed matrix layer (Tab 2). Individual wellstructured microcolonies or only individual attached cells were observed in almost equal numbers of Ukrainian isolates. Only three strains among tested $-L$. plantarum ONU 12, ONU 333 and ONU 355, covered roots with well-formed biofilms, but opposite to upper plant parts, biofilm maturation was not regular and gaps in the structure were observed.

As all the tested strains formed biofilms of equal level on upper parts of the plants, selection of strains with adhesive characteristics perspective for plant protection would rather include screening for attachment and biofilm formation on roots that on shoots, leaves or seeds. According to this reason, further experiments were carried out on plant roots. The level of initial attachment of bacterial cells to roots did not coincide with the ability of isolates to subsequent formation of biofilms (Tab 3).

Table 2 Amount of Lactobacillus plantarum strains (\%) with different characteristics of biofilms on roots of Lepidium sativum $\mathrm{L}$.

\begin{tabular}{|c|c|c|c|c|c|c|c|c|}
\hline \multirow{4}{*}{$\begin{array}{l}\text { Origin of } \\
\text { the strains }\end{array}$} & \multicolumn{8}{|c|}{ Characteristics of biofilms } \\
\hline & \multirow{2}{*}{\multicolumn{2}{|c|}{$\begin{array}{c}\text { on shoots, leaves and seed coat shells } \\
\text { well-formed with microcolonies } \\
\text { embedded in developed matrix layer }\end{array}$}} & & & \multicolumn{2}{|r|}{ on roots } & & \\
\hline & & & \multicolumn{2}{|c|}{$\begin{array}{l}\text { well-formed biofilm with } \\
\text { gaps in the structure }\end{array}$} & & $\begin{array}{l}\text { dividual well- } \\
\text { d microcolonies }\end{array}$ & \multicolumn{2}{|c|}{$\begin{array}{c}\text { individual attached cells without } \\
\text { microcolonies }\end{array}$} \\
\hline & $\begin{array}{l}\text { amount of the } \\
\text { strains }(\%)\end{array}$ & name of the strains & $\begin{array}{l}\text { amount of } \\
\text { the strains } \\
(\%)\end{array}$ & $\begin{array}{l}\text { name of the } \\
\text { strains }\end{array}$ & $\begin{array}{l}\text { amount } \\
\text { of the } \\
\text { strains } \\
(\%)\end{array}$ & $\begin{array}{l}\text { name of the } \\
\text { strains }\end{array}$ & $\begin{array}{l}\text { amount of the } \\
\text { strains }(\%)\end{array}$ & $\begin{array}{l}\text { name of the } \\
\text { strains }\end{array}$ \\
\hline France & $100 \%$ & $\begin{array}{c}\text { ONU } 351,352,353, \\
354,355,356,357, \\
359,362,363,364, \\
365,471\end{array}$ & $7.6 \%$ & ONU 355 & $77.0 \%$ & $\begin{array}{c}\text { ONU } 352,353, \\
354,356,357, \\
359,362,363, \\
364,471\end{array}$ & $15.4 \%$ & ONU 351,365 \\
\hline Ukraine & $100 \%$ & $\begin{array}{c}\text { ONU } 12,311,312, \\
313,333,335,337, \\
339,340,342,345, \\
348,349,350,472, \\
475,476\end{array}$ & $11.7 \%$ & $\begin{array}{l}\text { ONU } 12, \\
333\end{array}$ & $47.1 \%$ & $\begin{array}{l}\text { ONU } 311,312, \\
313,340,342 \\
345,349,350\end{array}$ & $41.2 \%$ & $\begin{array}{c}\text { ONU } 335,337 \\
339,348,472 \\
\quad 475,476\end{array}$ \\
\hline $\begin{array}{l}\begin{array}{l}\text { Reference } \\
\text { strains }\end{array} \\
\end{array}$ & $100 \%$ & $\begin{array}{c}\text { UCM B-2709, UCM } \\
\text { B-2694 }\end{array}$ & - & - & $100 \%$ & $\begin{array}{l}\text { UCM B-2709, } \\
\text { B-2694 }\end{array}$ & - & - \\
\hline
\end{tabular}

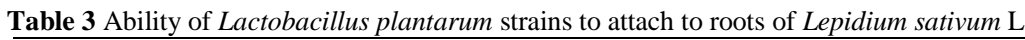

\begin{tabular}{|c|c|c|c|}
\hline Strain & $\begin{array}{c}\text { Amount of attached cells, } \\
\text { CFU/cm² }\end{array}$ & Strain & $\begin{array}{c}\text { Amount of attached cells, } \\
\text { CFU/cm }\end{array}$ \\
\hline \multicolumn{2}{|c|}{ France } & \multicolumn{2}{|c|}{ Ukraine } \\
\hline L. plantarum ONU 351 & $(2.1 \pm 0.3) \times 10^{3}$ & L. plantarum ONU 12 & $(6.5 \pm 0.2) \times 10^{4}$ \\
\hline L. plantarum ONU 352 & $(3.5 \pm 0.1) \times 10^{4}$ & L. plantarum ONU 311 & $(3.4 \pm 0.1) \times 10^{4}$ \\
\hline L. plantarum ONU 353 & $(2.6 \pm 0.5) \times 10^{4}$ & L. plantarum ONU 312 & $(2.8 \pm 0.2) \times 10^{4}$ \\
\hline L. plantarum ONU 354 & $(4.1 \pm 0.2) \times 10^{4}$ & L. plantarum ONU 313 & $(3.6 \pm 0.3) \times 10^{4}$ \\
\hline L. plantarum ONU 355 & $(7.8 \pm 0.2) \times 10^{4}$ & L. plantarum ONU 333 & $(5.4 \pm 0.4) \times 10^{4}$ \\
\hline L. plantarum ONU 356 & $(2.8 \pm 0.3) \times 10^{4}$ & L. plantarum ONU 335 & $(4.3 \pm 0.2) \times 10^{3}$ \\
\hline L. plantarum ONU 357 & $(3.5 \pm 0.7) \times 10^{4}$ & L. plantarum ONU 337 & $(2.8 \pm 0.5) \times 10^{3}$ \\
\hline L. plantarum ONU 359 & $(4.9 \pm 0.4) \times 10^{4}$ & L. plantarum ONU 339 & $(3.2 \pm 0.3) \times 10^{3}$ \\
\hline L. plantarum ONU 362 & $(5.1 \pm 0.5) \times 10^{4}$ & L. plantarum ONU 340 & $(4.1 \pm 0.2) \times 10^{4}$ \\
\hline L. plantarum ONU 363 & $(3.2 \pm 0.2) \times 10^{4}$ & L. plantarum ONU 342 & $(3.5 \pm 0.2) \times 10^{4}$ \\
\hline L. plantarum ONU 364 & $(3.1 \pm 0.1) \times 10^{4}$ & L. plantarum ONU 345 & $(3.6 \pm 0.7) \times 10^{4}$ \\
\hline L. plantarum ONU 365 & $(1.5 \pm 0.4) \times 10^{4}$ & L. plantarum ONU 348 & $(2.7 \pm 0.3) \times 10^{4}$ \\
\hline
\end{tabular}




\begin{tabular}{cccc}
\hline L. plantarum ONU 471 & $(3.7 \pm 0.3) \times 10^{4}$ & L. plantarum ONU 349 & $(4.5 \pm 0.6) \times 10^{4}$ \\
\hline Reference strains & & L. plantarum ONU 350 & $(1.6 \pm 0.4) \times 10^{4}$ \\
\hline L. plantarum UCM B-2709 & $(3.7 \pm 0.3) \times 10^{4}$ & L. plantarum ONU 472 & $(3.5 \pm 0.5) \times 10^{4}$ \\
\hline L. plantarum UCM B-2694 & $(3.1 \pm 0.1) \times 10^{4}$ & L. plantarum ONU 475 & $(2.9 \pm 0.2) \times 10^{4}$ \\
\cline { 3 - 4 } & & L. plantarum ONU 476 & $(4.8 \pm 0.5) \times 10^{3}$ \\
\hline
\end{tabular}

Level of attachment varied from $(7.8 \pm 0.2) \times 10^{4}$ to $(2.1 \pm 0.3) \times 10^{3} \mathrm{CFU} / \mathrm{cm}^{2}$ and depended on a strain.

From nine strains forming slight biofilms, only five strains were characterized by low adhesion to garden cress roots, with amount of attached cells from $2.1 \times 10^{3}$ to $4.8 \times 10^{3} \mathrm{CFU} / \mathrm{cm}^{2}$. Others demonstrated the same level of attachment as the strains that formed microcolonies and well-developed biofilms (Tab 3).

Gene $\operatorname{pln} A$ was found in $28.1 \%$ of all studied isolates (L. plantarum ONU 333 , $342,345,348,349,350,355,362,364)$. All $p \ln A$ possessing strains except ONU 348 were characterized by formation of well-developed microcolonies and biofilms. Strains $L$. plantarum ONU 333 and ONU 355 with the highest level of biofilm formation were $p \ln A$-positive.

\section{Competitive adhesion}

Treatment of biofilms of A. tumefaciens $\mathrm{pJZ}$ on roots of tomato seedlings with suspensions of lactobacilli (L. plantarum ONU 12, ONU 333 and ONU 355) resulted in complete disruption of the pathogen biofilms. No A. tumefaciens $\mathrm{pJZ}$ cells were found on roots (Fig 3).

If agrobacteria were added to already formed biofilms of L. plantarum ONU 355 some cells of pathogens could integrate into the biofilm in $25 \%$ of tested samples (Fig 3). But treatment with suspensions of $L$. plantarum ONU 12 and $L$. plantarum ONU 333 completely eliminated the pathogen (Fig 3).
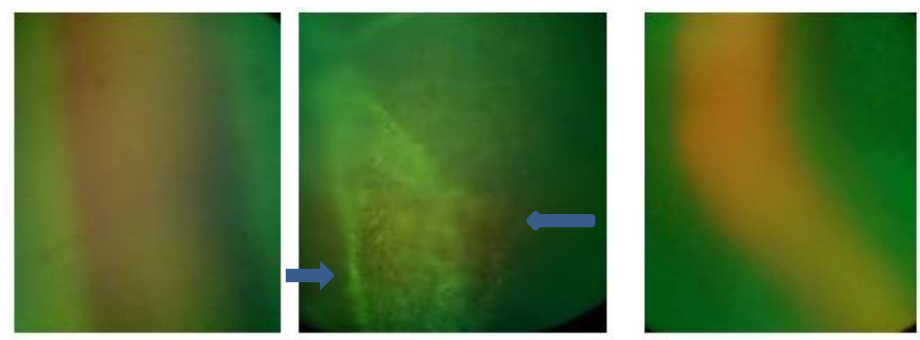

A
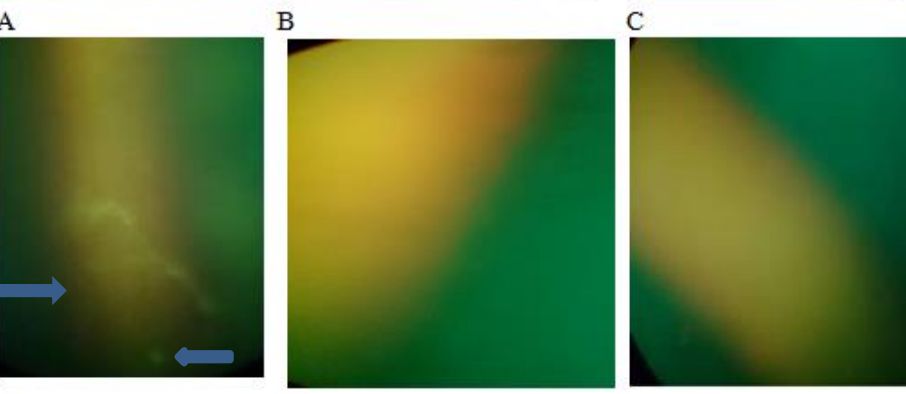

D $\mathrm{E}$

F

Figure 3 Competitive adhesion of L. plantarum and A. tumefaciens pJZ: A negative control (inoculation with $L$. plantarum 12 ); B - positive control (inoculation with A. tumefaciens pJZ, developed biofilm of fluorescent GFPexpressing cells of the pathogen covers all the root surface, pointed with arrows); $\mathrm{C}$ - treatment of A. tumefaciens pJZ biofilms with L. plantarum ONU 355 (no fluorescent cells of the pathogen); D - addition of A. tumefaciens pJZ to biofilm of L. plantarum ONU 355 (fluorescent cells of the pathogen on root surface, pointed with arrows); $\mathrm{E}$ - addition of $A$. tumefaciens $\mathrm{pJZ}$ to biofilm of $L$ plantarum ONU 12 (no fluorescent cells of the pathogen); F - simultaneous inoculation with L. plantarum ONU 333 and A. tumefaciens pJZ (no fluorescent cells of the pathogen)

Simultaneous inoculation of test plant roots with lactobacilli and agrobacteria also demonstrated the protective effect of L. plantarum (Fig 3). In case of the strains L. plantarum ONU 12 and ONU 355 complete elimination of agrobacteria was observed. A. tumefaciens $\mathrm{pJZ}$ formed mixed biofilms with L. plantarum ONU 333 in $16.7 \%$, and $83.3 \%$ root samples inoculated with this strain remained free from the pathogen.

\section{RAPD-PCR profiles}

All studied strains of $L$. plantarum after the construction of a phylogenetic tree have been referred to three clusters A, B and C (Fig 4).

The majority of strains has been included in the cluster $\mathrm{A}$, which was divided into five subclusters (A1 - A5). Most of the strains belonged to the subcluster A1 (Fig 4). No association with the geographical origin of the strains was observed in this cluster. Thus, the subcluster A1.1 included four strains from Ukraine - ONU 339,
313, 311 and 349, and three strains from France - ONU 359, 354 and 356 Reference strains (L. plantarum UCM B2709 and L. plantarum UCM B2694) were also found in this subcluster. A similar situation was observed for the subcluster A1.2, which included strains ONU 353, 362, 364, 471 (France), and ONU 476, 333 (Ukraine) (Fig 4).

Most of the internal nodes of subcluster A1 of the phylogenetic tree were confirmed by the statistical significance of the order of branching at the level 57 $65 \%$.

The subcluster A4 was the second large subcluster by the number of classified strains. As in the previous case, the formation of groups did not reflect the geographical origins of the strains (Fig 4). The statistical significance of the order of branching for nodes of this subcluster was slightly smaller $-28-46 \%$. The significance of the branching $<50 \%$ indicates that these strains would belong to different subspecies and increasing of the sample will form separate clusters.

The high value of statistical significance during the bootstrap analysis was noted for the subcluster A5 containing strains L. plantarum ONU 12 (Ukraine) and ONU 355 (France). A distinctive feature of this cluster was the ability of the strains to form well developed biofilms (see Tab 2).

The subclusters A2 and A3 included two strains (Fig 4), and the statistical significance of branching order for them was minimal (4-6\%).

As the result of the study of the phylogenetic tree topology, two separate clusters - B and C were identified (Fig 4). Significance of the order of branching internal nodes $-51 \%$ and $33 \%$ respectively, was the reason of their separation from all other strains. These clusters contained the strains isolated only in Ukraine.

\section{DISCUSSION}

Presented results show the high capability of the studied $L$. plantarum strains to attach to shoots and leaves of Lepidium sativum L. seedlings and straindependent ability to attach to roots. These data are in agreement with the hypothesis of Hammes and Hertel (2006) who suggested that owing to their high potential to form extracellular matrix, lactobacilli could be the components of the biofilms on plant surfaces or even be able to initiate biofilm formation (Hammes and Hertel, 2006). This hypothesis was based on the investigation of Morris et al. (1997) who revealed that $10-66 \%$ of the total cultivable microorganisms from biofilms on plant surfaces are represented by Grampositive bacteria. Biofilms, the same as in case of this study, were found on all parts of the leaves - margin, base, upper and lower surfaces. In nature, biofilms on leaves are composed of exopolymer matrix and various microbial morphotypes - bacteria, filamentous fungi and yeasts (Morris et al., 1997), whereas in the studied case lactobacilli were able to form a monospecies biofilm in absence of all other microorganisms.

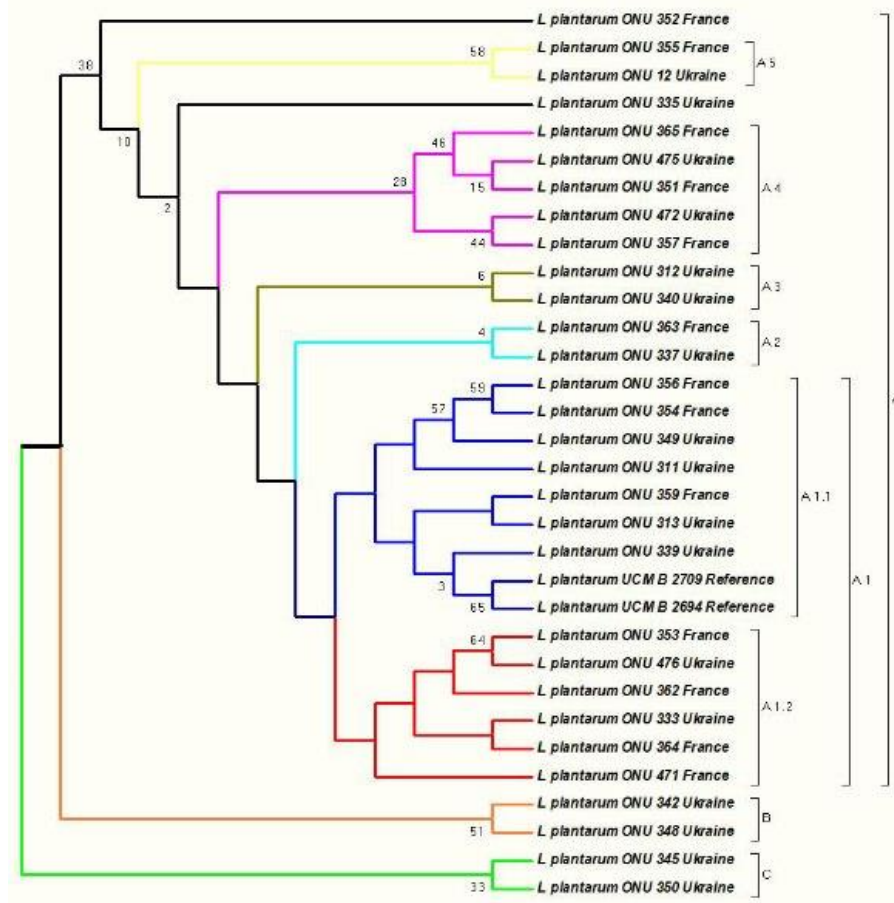

Figure 4 The phylogenetic tree of the tested L. plantarum strains built on the results of RAPD-PCR using the method of maximum likelihood and the JukesCantor model. Numerals show a statistically significant branching order (in \%) determined by a bootstrap analysis for 1000 alternative replicas 
The lower levels of biofilm formation on roots coincide with the scarce evidences about the occurrence of LAB in rhizosphere (Hammes and Hertel, 2006). The same concerns soil (Fhoula et al., 2013), although some authors described soil as a common source for the isolation of LAB including lactobacilli (Chen $\boldsymbol{e t}$ al. 2005; Yanagida et al., 2006). L. plantarum was found in rhizosphere of olive trees and desert truffles in Tunisia (Fhoula et al., 2013) and in rhizosphere of Hibiscus esculentum in Nigeria (Oyeyiola et al., 2013). Our investigations showed the possibility of $L$. plantarum to attach to roots of seedlings on example of Lepidium sativum. The capability to form biofilms on roots was lower than in case of shoots and leaves. Whereas the ability to form biofilms on the upper parts of the plants was equally high for all studied L. plantarum strains, biofilm formation on the roots appeared strain-specific.

In experiments of Calasso et al. (2013) strain DC400 of L. plantarum cultivated on a medium supplemented with chemically synthesized PlnA significantly increased the capability to form biofilms on polystyrene pegs and to attach to Caco-2 human colon carcinoma cell line. Such results together with the investigation of exoproteome of the studied strain enabled authors to conclude that the adhesion and biofilm formation were mediated by the peptide pheromone PlnA (Calasso et al., 2013). In our experiments, indeed, only one strain with $p \ln A$ in its genome ( $L$. plantarum ONU 348) exhibited low level of biofilm formation. Other $p \ln A$ possessing strains formed microcolonies or biofilms with developed matrix. These results indicate that strains carrying $p \ln A$ also had the better ability to form biofilms on plant root surfaces. L. plantarum ONU 12 possessing no $p \ln A$ gene was an exclusion - bacteria of this isolate formed welldeveloped biofilms despite of the absence of the gene. Describing the succession of LAB in fermenting cucumbers, Singh and Ramesh (2008) pointed out the time-dependent emergence of $\mathrm{P} \ln \mathrm{A}$ producers during the late stages of fermentation. Together with pediococci, PlnA producers were prevalent in population of bacteriocinogenic strains (Singh and Ramesh, 2008). In our study the percentage of potential PlnA producers among the strains constituted $28.1 \%$. Lactobacilli could interfere the formation of biofilms by plant pathogen on an example of A. tumefaciens pJZ. The effect was strain dependent and resulted in complete elimination of pathogens from tomato roots in $75.0-100 \%$ of tested samples depending on a method of inoculation. Antagonistic action of lactobacilli against some phytopathogenic bacteria - Xanthomonas campestris, Pseudomona syringae, Erwinia carotovora, have been demonstrated by well-diffusion method and on test plants by estimation of disease symptoms (Visser et al., 1986; Trias et al., 2008; Dalirsaber et al., 2012). We found out that inhibition of the pathogen could occur already on a step of attachment and biofilm formation - the first step of disease pathogenesis. Lactobacilli could compete with the phytopathogen, protect plant surface and disrupt mature biofilms of the pathogen. The results of RAPD-PCR analysis indicated that most of the studied $L$ plantarum strains from two different geographical regions - France and Ukraine, were similar to each other and formed a monophyletic group. However, the presence of clusters B and C indicated the existing paraphilia within the studied L. plantarum.

The high value of statistical significance during the boot strap analysis was noted for the subcluster A5 containing strains L. plantarum ONU 12 (Ukraine) and ONU 355 (France). A distinctive feature of this cluster was the high ability of the strains to form biofilms (see Tab 2).

Modern investigations have elucidated that L. plantarum strains cluster together according to their particular food niche (Siezen et al., 2010). In case of $L$ plantarum from ovine milk and cheese, analysis based on RAPD-PCR resulted in seven clusters showing the diversity between the isolates from the two mentioned sources. Moreover, the differences between the geographical regions of isolation could be clearly seen (Oneca et al., 2003). In case of L. plantarum from plants, isolates from maize fermented product potopoto could be divided into the two main groups (Ben Omar et al., 2008). Strains from must of grape gathered in one region of Italy appeared closely related (Spano et al., 2002). At the opposite, a significant genetic diversity of $L$. plantarum strains from Patagonian red wines was revealed (Bravo-Ferrada et al., 2013). When strains from two regions of grapevine cultivation in Greece were studied, most of the L. plantarum vineyard populations showed a high degree of genetic similarity. Two RAPD-PCR patterns were common between the studied regions, but no clustering according to the zone of origin was revealed (Nisitou et al., 2015). The same was observed in our study - the strains from two distant geographical zones could not be clearly clustered basing on the place of origin. Only clusters B and C with the fewest number of strains contained isolates from Ukraine only.

\section{CONCLUSION}

L. plantarum isolated from products of plant origin (grape must and pickles) exhibited ability to attach to Lepidium sativum seedlings and form biofilms. On roots isolates from France preferentially formed separated microcolonies withou developed matrix layer, whereas almost half of Ukrainian isolates exhibited the attachment of individual cells without formation of microcolonies. Ability of the strains to attach to plant roots and to form biofilms did not coincide. Comparison of RAPD profiles and abilities to form biofilms showed no association with the geographical origin of the L. plantarum strains isolated in France and Ukraine One subcluster - A5 - included two strains with the high level of biofilm formation: L. plantarum ONU 12 (Ukraine) and ONU 355 (France). Since RAPD-typing could not find certain differences between strains from the two geographically distant zones, further investigations should be carried out to select a method of typing the isolates of L. plantarum to trace their origin. Lactobacilli could eliminate biofilms of the phytopathogen A. tumefaciens $\mathrm{pJZ}$ from tomato roots. Such antagonistic effect against pathogenic bacteria as well as ability to form developed biofilms on plant surfaces need further detailed investigation for possible practical implementation in plant protection and food industry.

Acknowledgments: This work was supported by a bilateral French-Ukrainian project "Dnipro" (2011-2012, 2015-2016) granted by the Ministry of Foreign and European Affairs of France and the Ministry of Education and Science of Ukraine, and by the individual grant for Andrii Merlich (Campus-France 2013 2017) supported by the French Embassy in Ukraine.

\section{REFERENCES}

BARAHONA, E., NAVAZO, A., YOUSEF-CORONADO, F., AGUIRRE DE CÁRCER, D., MARTÍNEZ-GRANERO, F., ESPINOSA-URGEL, M., MARTÍN, M., RIVILLA, R. 2010. Efficient rhizosphere colonization by Pseudomonas fluorescens f113 mutants unable to form biofilms on abiotic surface. Environm $\quad$ Microbiol, 12(12), 3195. https://doi.org/10.1111/j.1462-2920.2010.02291.x

BAUER, R., DICKS, L.M.T. 2004. Control of malolactic fermentation in wine. A Review. S. Afr. J. Enol. Vitic., 25(2), 74-88. http://dx.doi.org/10.21548/25-2-2141

BEN OMAR, N., ABRIOUEL, H., KELEKE, S., VALENZUELA, A. S. MARTINEZ-CANAMERO, M., LOPEZ, R. L., ORTEGA, E., GALVEZ, A. 2008. Bacteriocin-producing Lactobacillus strains isolated from potopoto, a Congolese fermented maize product, and genetic fingerprinting of their plantaricin operons. Int Journal Food Microbiol, 127, 18-25. https://doi.org/10.1016/j.ijfoodmicro.2008.05.037

BERTANI, G. 1951. Studies on lysogenesis. I. The mode of phage liberation by lysogenic Escherichia coli. J Bacteriol, 62, 293-300.

BRAVO-FERRADA, B. M., HOLLMANN, A., DELFEDERICO, L., VALDES LA HENS, D., CABALLERO, A., SEMORILE, L. 2013. Patagonian red wines: selection of Lactobacillus plantarum isolates as potential starter cultures for malolactic fermentation. World J Microbiol Biotechnol, 29, 1537-1549. https://doi.org/10.1007/s11274-013-1337-x

BRISSET, M. N., RODRIGUEZ-PALENZUELA, P., BURR, T. J., COLLMER, A. 1991. Attachment, chemotaxis, and multiplication of Agrobacterium tumefaciens biovar 1 and biovar 3 on grapevine and pea. Appl Environm Microbiol, 57, 3178-3182

BURR, T. J., OTTEN, L. 1999. Crown gall of grape: biology and disease management. Annu Rev Phytopathol, 37, 53-80. http://doi.org/10.1146/annurev.phyto.37.1.53

CALASSO, M., DI CAGNO, R., DE ANGELIS, M., CAMPANELlA, D. MINERVINI, F., GOBETTI, M. 2013. Effects of the peptide pheromone plantaricin A and cocultivation with Lactobacillus sanfranciscensis DPPMA174 on the exoproteome and the adhesion capacity of Lactobacillus plantarum DC400. Appl Environ Microbiol, $\quad 79, \quad 2657-2669$ http://doi.org/10.1128/AEM.03625-12

CHEN, Y. S., YANAGIDA, F., SHINOHARA, T. 2005. Isolation and identification of lactic acid bacteria from soil using an enrichment procedure. Lett Appl Microbiol, 40, 195-200. http://doi.org/10.1111/j.1472-765X.2005.01653.x

ÇON, A. H., KARASU, N. 2009. Determination of antagonistic starter cultures for pickle and olive fermentation processes. Czech Journal of Food Sciences, 27, 185-193.

DALIRSABER, J. M., KHOSRO, I., GHASEMI, M. F., TABRIZI, S. S. KH 2012. Antagonism of Lactobacillus species against Xanthomonas campestris isolated from different plants. Journal of Applied Environmental and Biological Sciences, 9, 480-484.

DE MAN, J. C., ROGOSA, M., SHARPE, M. E. 1960. A medium for the cultivation of lactobacilli. J Appl Bacteriol, 23, 130-135. https://doi.org/10.1111/j.1365-2672.1960.tb00188.x

DIEP, D. B., HAVARSTEIN, L. S., NES, I. F. 1996. Characterization of the locus responsible for bacteriocin production in Lactobacillus plantarum $\mathrm{C} 11 . \mathrm{J}$ Bacteriol, 178, 4472-4483.

DU PLESSIS, H. W., DICKS, L. M., PRETORIUS, I. S., LAMBRECHTS, M G., DU TOIT, M. 2004. Identification of lactic acid bacteria isolated from South African brandy base wines. Int $J$ Food Microbiol, 91, 19-29. https://doi.org/10.1016/S0168-1605(03)00335-0

FHOULA, I., NAJJARI, A., TURKI, Y., JABALLAH, S., BOUDABOUS, A., OUZARI, H. 2013. Diversity and antimicrobial properties of lactic acid bacteria isolated from rhizosphere of olive trees and desert truffles of Tunisia. Biomed Research International, 2013:405708, Epub $2013 \quad$ Sep 14. https://doi.org/10.1016/j.ijfoodmicro.2008.05.037

GALANIS, A., KOURKOUTAS, Y., TASSOU, C.C., CHORIANOPOULOS, N. 2015. Detection and identification of probiotic Lactobacillus plantarum 
strains by Multiplex PCR using RAPD-derived primers. Int J Mol Sci, 16 25141-25153. https://doi.org/10.3390/ijms161025141

HAMMES, W. P., HERTEL, C. 2006. The genera Lactobacillus and Carnobacterium. In: Dworkin, M., Falkow, S., Rosenberg, E., Schleifer, K.-H., Stackebrandt, E. (ed), The Prokaryotes. A Handbook on the Biology of Bacteria: Firmicutes, Cyanobacteria, (Vol. 4). New York: Springer-Verlag, 1140 p. ISBN 978-0-387-30744-2.

HODA, H. A., YOMNA, M. A., SHADIA, M. A.-A. 2011. In vivo efficacy of lactic acid bacteria in biological control against Fusarium oxysporum for protection of tomato plant. Life Science Journal, 8, 462-468.

JUKES, T. H., CANTOR, C.R. 1969. Evolution of protein molecules. In: Munro, H. N. (ed), Mammalian Protein Metabolism. New York: Academic Press, 590 p. ISBN 9781483272900.

KNOLL, C., DIVOL, B., DU TOIT, M. 2008. Genetic screening of lactic acid bacteria of oenological origin for bacteriocin-encoding genes. Food Microbiol, 25, 983-991. http://doi.org/10.1016/j.fm.2008.06.010

LAFON-LAFOURCADE, S., CARRE, E., RIBEREAU-GAYON, P. 1983 Occurrence of lactic acid bacteria during the different stages of vinification and conservation of wines. Applied and Environmental Microbiology, 46, 874-880. LUTZ, M. P., MICHEL, V., MARTINEZ, C., CAMPS, C. 2012. Lactic aci bacteria as biocontrol agents of soil-born pathogens. Biological control of fungal and bacterial plant pathogens. International Organization for Biological and Integrated Control West Palaearctic Regional Section Bulletin, 78, 285-288. MAHENTHIRALINGAM, E, MARCHBANK, A, DREVINEK, $\mathrm{P}$ GARAIOVA, I, PLUMMER, S. 2009. Use of colony-based bacterial strain typing for tracking the fate of Lactobacillus strains during human consumption. BMC Microbiology, 9(251). https://doi.org/10.1186/1471-2180-9251

MARTINS, E. M. F., RAMOS, A. M., VANZELA, E. S. L., STRINGHETA, P. C., DE OLIVEIRA PINTO, C. L., MARTINS, J. M. 2013. Products of vegetable origin: a new alternative for the consumption of probiotic bacteria. Food Research International,

51 ,

$764-770$

https://doi.org/10.1016/j.foodres.2013.01.047

MORRIS, C. E., MONIER, J.-M., JACQUES, M.-A. 1997. Methods for observing microbial biofilms directly on leaf surfaces and recovering them for isolation of culturable microorganisms. Appl Environ Microbiol, 63, 1570-1576. NISITOU, A. A., DOUROU, D., FILIPPOUSI, M.-E., DIAMANTEA, E., FRAGKOULIS, P., TASSOU, C., BANILAS, G. 2015. Genetic and technological characterization of vineyard- and winery-associated lactic acid bacteria. BioMed Research International, Article ID 5082554 http://dx.doi.org/10.1155/2015/508254

ONECA, M., IRIGOYEN, A., ORTIGOSA, M., TORRE, P. 2003. PCR and RAPD identification of Lactobacillus plantarum strains isolated from ovine milk and cheese. Geographical distribution of strains. FEMS Microbiol Lett, 227, 271277. https://doi.org/10.1016/S0378-1097(03)00691-8

OYEYIOLA, G. P, AREKEMASE, M. O, SULE, I. O., AGBABIAKA, T. O. 2013. Rhizosphere bacterial flora of Okro (Hibiscus esculentus). Science International (Lahore), 25, 273-276.

PIASECKA-JOZWIAK, K., ROZMIERSKA, J., CHABLOWSKA, B., STECKA, K. M., SKAPSKA, S., KLISZCZ, M., SZKUDZINSKARZESZOWIAK, E. 2013. Starter cultures for lactic acid fermentation of sweet pepper, pattypan squash and tomatoes. Polish Journal of Food and Nutrition Sciences, 63, 95-102. https://doi.org/10.2478/v10222-012-0068-2

PISANO, M. B., PATRIGNANI, F., COSENTINO, S., GUERZONI, M. E. FRANZ C. M. A. P., HOLZAPFEL, W. H. 2011. Diversity and functional properties of Lactobacillus plantarum-group strains isolated from Italian cheese products. Diary Science and Technology, 91, 65-76. https://doi.org/10.1051/dst/2010037

REINA, L. D., FLEMING, H. P., BREIDT, F. JR. 2002. Bacterial contamination of cucumber fruit through adhesion. $J$ Food Prot, 65, 1881-1887. https://doi.org/10.4315/0362-028X-65.12.1881

REMIGER, A., EHRMANN, M. A., VOGEL, R. F. 1996. Identification of bacteriocin genes in lactobacilli by polymerase chain reaction (PCR). Syst Appl Microbiol, 19, 28-34. https://doi.org/10.1016/S0723-2020(96)80005-1

SIEZEN, R. J., TZENEVA, V. S., CASTIONI, A., WELS, M., PHAN, H. T. K., RADEMAKER, J. L. W., STARRENBURG, M. J. C., KLEEREBEZEM, M., MOLENAAR, D., VAN HYLCKAMA VLIEG, J. E. T. 2010. Phenotypic and genomic diversity of Lactobacillus plantarum strains isolated from various environmental niches. Environ Microbiol, 12, 758

773. https://doi.org/10.1111/j.1462-2920.2009.02119.x

SINGH, A. K., RAMESH, A. 2008. Succession of dominant and antagonistic lactic acid bacteria in fermented cucumber: insights from a PCR-based approach. Food Microbiol, 25, 278-287. https://doi.org/10.1016/j.fm.2007.10.010

SONG, Y., SUN, Z., GUO, C., WU, Y., LIU, W., YU, J., MENGHE, B., YANG R., ZHANG, H. 2016. Genetic diversity and population structure of Lactobacillus delbrueckii subspecies bulgaricus isolated from naturally fermented dairy foods. Scientific Reports, 6, 22704. http://doi.org/10.1038/srep22704

SPANO, G., BENEDUCE, L., TARANTINO, D., ZAPPAROLI, G., MASSA, S. 2002. Characterization of Lactobacillus plantarum from wine must by PCR species-specific and RAPD-PCR. Lett Appl Microbiol, 35, 370-374. https://doi.org/10.1046/j.1472-765X.2002.01200.x

TALLON, R., ARIAS, S., BRESSOLLIER, P., URDACI, M. C. 2006. Strainand matrix-dependent adhesion of Lactobacillus plantarum is mediated by proteinaceous bacterial compounds. $J$ Appl Microbiol, 102, 442-451. https://doi.org/10.1111/j.1365-2672.2006.03086.x

TAMURA, K., DUDLEY, J., NEI, M., KUMAR, S. 2007. MEGA4: Molecular Evolutionary Genetics Analysis (MEGA) software version 4.0. Mol Biol Evol, 24, 1596-1599. https://doi.org/10.1093/molbev/msm092

TAMURA, K., PETERSON, D., PETERSON, N., STECHER, G., NEI, M, KUMAR, S. 2011. MEGA5: molecular evolutionary genetics analysis using maximum likelihood, evolutionary distance, and maximum parsimony methods. Mol Biol Evol, 28, 2731-2739. https://doi.org/10.1093/molbev/msr121

TESTA, B., LOMBARDI, S.J., TREMONTE, P., SUCCI, M., TIPALDI, L., PANELLA, G., SORRENTINO, E., LORIZZO, M., COPPOLA, R. 2014 Biodiversity of Lactobacillus plantarum from traditional Italian wines. $J$ Microbiol Biotechnol 30(8), 2299-2305. https://doi.org/10.1007/s11274-0141654-8

TRIAS, R., BAÑERAS, L., MONTESINOS, E., BADOSA, E. 2008. Lactic acid bacteria from fresh fruit and vegetables as biocontrol agents of phytopathogenic bacteria and fungi. Int Microbiol, 11, 231-236. https://doi.org/10.2436/20.1501.01.66

VELEZ, M. P., DE KEERSMAECKER, S. C. J., VANDERLEYDEN, J. 2007. Adherence factors of Lactobacillus in the human gastrointestinal tract. FEMS Microbiol Lett, 276, 140-148. https://doi.org/10.1111/j.1574-6968.2007.00908.x VISSER, R., HOLZAPFEL, W. H., BEZUIDENHOUT, J. J., KOTZE, J. M 1986. Antagonism of lactic acid bacteria against phytopathogenic bacteria. Appl Environ Microbiol, 52, 552-555.

YANAGIDA, F., CHEN, Y. S., SHINOHARA, T. 2006. Searching for bacteriocin-producing lactic acid bacteria in soil. J Gen Appl Microbiol, 52, $21-$ 28. https://doi.org/10.2323/jgam.52.21 